\title{
The role of dietary fat in body fatness: evidence from a preliminary meta-analysis of ad libitum low-fat dietary intervention studies
}

\author{
Arne Astrup $^{1}$, Louise Ryan ${ }^{1}$, Gary K. Grunwald ${ }^{2}$, Mette Storgaard ${ }^{1}$, \\ Wim Saris ${ }^{3}$, Ed Melanson ${ }^{2}$ and James O. Hill ${ }^{2}$ \\ ${ }^{1}$ Research Department of Human Nutrition \& LMC, The Royal Veterinary and Agricultural University, \\ Frederiksberg, Denmark \\ ${ }^{2}$ Center for Human Nutrition, University of Colorado Health Sciences Center, Denver, CO, USA \\ ${ }^{3}$ University of Maastricht, Maastricht, The Netherlands
}

\begin{abstract}
The role of high-fat diets in weight gain and obesity has been questioned because of inconsistent reports in the literature concerning the efficacy of ad libitum low-fat diets to reduce body weight. We conducted a meta-analysis of weight loss occurring on ad libitum low-fat diets in intervention trials, and analysed the relationship between initial body weight and weight loss. We selected controlled trials lasting more than 2 months comparing ad libitum low-fat diets with a control group consuming their habitual diet or a medium-fat diet ad libitum published from 1966 to 1998. Data were included from 16 trials with a duration of 2-12 months, involving 1728 individuals. No trials on obese subjects fulfilled the inclusion criteria. The weighted difference in weight loss between intervention and control groups was $2.55 \mathrm{~kg}$ (95\% CI, $1.5-3.5 ; P<0 \cdot 0001)$. Weight loss was positively and independently related to pre-treatment body weight $(r=0.52$, $P<0.05)$ and to reduction in the percentage of energy as fat $(0.37 \mathrm{~kg} / \%, P<0.005)$ in unweighted analysis. Extrapolated to a BMI of about $30 \mathrm{~kg} / \mathrm{m}^{2}$ and assuming a $10 \%$ reduction in dietary fat, the predicted weight loss would be $4.4 \mathrm{~kg}(95 \% \mathrm{CI}, 2.0$ to $-6.8 \mathrm{~kg}$ ). Because weight loss was not the primary aim in 12 of the 16 studies, it is unlikely that voluntary energy restriction contributed to the weight loss. Although there is no evidence that a high intake of simple sugars contributes to passive overconsumption, carbohydrate foods with a low glycaemic index may be more satiating and exert more beneficial effects on insulin resistance and cardiovascular risk factors. Moreover, an increase in protein content up to $25 \%$ of total energy may also contribute to reducing total energy intake. In conclusion, a low-fat diet, high in protein and fibre-rich carbohydrates, mainly from different vegetables, fruits and whole grains, is highly satiating for fewer calories than fatty foods. This diet composition provides good sources of vitamins, minerals, trace elements and fibre, and may have the most beneficial effect on blood lipids and blood-pressure levels. A reduction in dietary fat without restriction of total energy intake prevents weight gain in subjects of normal weight and produces a weight loss in overweight subjects, which is highly relevant for public health.
\end{abstract}

Low-fat diets: Weight loss: Obesity: Humans: Body weight regulation

\section{Introduction}

The robustness of the data providing the evidence for a causal link between dietary fat and obesity has recently been challenged by statements such as "Diets high in fat do not appear to be the primary cause of the prevalence of excess body fat in our society, and reductions in [dietary] fat will not be the solution", and "in the longer term, fat consumption within the range of $18-40 \%$ appears to have little if any effect on body fatness" (Katan et al. 1997; Willett et al. 1998). As a consequence it has been suggested that saturated fat should be replaced by monounsaturated fat rather than by carbohydrate. This advice poses the risk that the current fat consumption, which already exceeds the recommended level, may be further increased. However, all lines of evidence linking dietary fat with obesity should be taken into consideration.

\footnotetext{
*Corresponding author: A. Astrup, fax +45 35282483, email ast@kvl.dk
} 


\section{Experimental studies on diet composition and energy intake}

In considering the problem of weight gain and obesity, the important issue is to determine the nature of the dietary components which facilitate consumption and lead to a positive energy balance. An active area of interest involves comparisons of fat and carbohydrate. Subjects exposed to high-fat foods for several weeks tend to overconsume energy. This effect depends largely on the high energy density of the high-fat foods, and the overeating effect has been referred to as passive overconsumption (Stubbs et al. 1995). It should be noted that the stimulatory effect of fatty foods on energy intake is due not only to their high energy density, but also to the probable facilitating action of fat in the mouth. It has been known for many years that offering subjects high-fat or high-carbohydrate foods which have been manipulated to be equally energy dense eliminates the high-fat overeating phenomenon in normal, non-genetically predisposed individuals.

The passive overconsumption effect of dietary fat on energy intake is due to an action during consumption (it is an intra-meal effect). The large amounts of fat energy consumed do not appear to generate equivalent effects on post-ingestive satiety. Therefore fat has a proportionally weaker effect on satiety relative to the amount of energy consumed. In studies where energetically equivalent preloads of fat and carbohydrate have been delivered, it appears that fat does exert a weaker satiating effect (on a Joule for Joule basis) than the other macronutrients.

A large body of short-term studies on appetite and energy intake unequivocally show that fat is less satiating than carbohydrate and protein when compared Joule for Joule, and that high-fat foods are more likely to induce passive overconsumption and weight gain than low-fat foods.

\section{Observational studies linking diet composition to obesity}

Numerous cross-sectional studies have clearly demonstrated positive associations between the proportion of total energy intake covered by fat and body fatness, and inverse associations between carbohydrate intake and body fatness. In contrast, a number of longitudinal studies have been unable to establish any association between self-reported dietary fat and carbohydrate intakes, and subsequent weight change. However, evidence based on observational studies looking for associations between habitual dietary macronutrient intakes and body fatness have a number of limitations due to their reliance on information about dietary intakes given by the subjects under examination (Astrup et al. 1997). Valid information on dietary fat intake is difficult to achieve in populations that are recommended to reduce fat intake (Bennett et al. 1992), because they may either eat a healthier diet during the dietary survey, or they may underreport fat intake. Furthermore, because fat oxidation is not increased in response to acute increases in fat intake, day-today fluctuations in dietary fat intake, which are not captured by reporting average fat intake, could lead to episodic bouts of fat storage. It is well established that overweight and obese subjects under-report their energy intake by 30-40\% (Prentice et al. 1986), and fat may be over-represented in this under-reporting. Studies in health-conscious populations show that high-fat foods are under-reported whereas low-fat foods are over-reported (Radimer \& Harvey, 1998). It seems to be easier to demonstrate associations between dietary fat intake and subsequent weight changes in lesshealth-conscious populations, such as in China (Paeratakul et al. 1998), than in the EU and the USA (Kant et al. 1995).

One may therefore question the validity of the dietary surveys reporting a decrease in fat consumption in the population. The surveys' estimates of dietary fat energy percentage in the USA show a decrease from $42 \%$ in 1965 to $37 \%$ in 1987 , whereas per capita values of fat intake and dietary fat energy percentage based on food availability increased from 42 to 43 energy per cent in the same period (Schoeller, 1990). Although the food-disappearance data do not include some types of food loss and waste (e.g. trimming fat from meats), and commodities used in pet foods are not subtracted from the total amounts available in the food supply, the increasing lack of agreement strongly suggests a substantial under-reporting of dietary fat intake in the surveys. This is not surprising, as one would expect subjects to report more healthy eating habits when asked to give information to nutrition experts. Moreover, the underreporting of energy and fat consumption among obese subjects may have an increasing impact in surveys of populations in which the majority are either overweight or obese.

In conclusion, cross-sectional studies consistently support the finding that a high-fat, low-carbohydrate diet contributes to the maintenance of the obese condition (Bray \& Popkin, 1998). However this consistent outcome should not be given major weight in assessing the relationship between dietary fat and body fat, because of the methodological limitations in obtaining valid information about dietary macronutrient intakes in diet-conscious and overweight populations.

\section{Intervention studies}

Randomized, controlled, ad libitum low-fat, high-carbohydrate intervention studies show mean weight loss ranging between 0 and $10 \mathrm{~kg}$ in the intervention groups, as compared to control groups maintaining their usual diet or consuming a medium- to high-fat diet (Astrup et al. 1997; Bray \& Popkin, 1998). This large variability and inconsistent outcome have created doubt about the effectiveness of a low-fat diet in the prevention and treatment of overweight and obesity, and questioned the role of dietary fat in body fatness. However, based on 28 intervention trials Bray and Popkin found that a reduction of $10 \%$ in the proportion of energy from fat was associated with a reduction in weight of $16 \mathrm{~g} / \mathrm{d}$, which corresponds to a weight loss of $2.9 \mathrm{~kg}$ over 6 months (Bray \& Popkin, 1998). We have further explored the effect of ad libitum low-fat diets by conducting a meta-analysis.

\section{Meta-analysis on ad libitum low-fat diets}

\section{Search and selection procedure}

The initial search revealed 217 publications. We then excluded studies if the intervention period was less than 
Table 1. Characteristics of 16 controlled trials of ad libitum low-fat diets on body weight

\begin{tabular}{|c|c|c|c|c|c|c|c|c|c|}
\hline Author (year) & Design & Goal & Duration & Group & $\begin{array}{l}\text { Gender } \\
\text { (F/M) }\end{array}$ & $\begin{array}{c}\mathrm{BMI} \\
\left(\mathrm{kg} / \mathrm{m}^{2}\right)\end{array}$ & $\begin{array}{l}\text { Weight loss } \\
\text { (kg) (SD) }\end{array}$ & $\begin{array}{l}\text { Weight loss } \\
\text { difference } \\
\text { (kg) }(95 \% \mathrm{Cl})\end{array}$ & $\begin{array}{c}\text { Change in dietary } \\
\text { fat energy } \\
\text { (\%) (SD) }\end{array}$ \\
\hline Lee-Han et al. (1988) & Randomized & Breast dysplasia & 12 months & I & $\begin{array}{l}29 / 0 \\
28 / 0\end{array}$ & $\begin{array}{l}23 \cdot 3 \\
22 \cdot 3\end{array}$ & $\begin{array}{c}-0.9(12.3) \\
0.6(7.3)\end{array}$ & $1.5(-3.7$ to 6.7$)$ & $\begin{array}{c}-10.6(11.4) \\
+0.2(9.5)\end{array}$ \\
\hline Boyd et al. (1990) & Randomized & Blood lipids & 12 months & I & $\begin{array}{l}100 / 0 \\
106 / 0\end{array}$ & $\begin{array}{l}22 \cdot 4 \\
22 \cdot 8\end{array}$ & $\begin{array}{r}-1.0(9.8) \\
0.0(9.4)\end{array}$ & $1.0(-1.6$ to $3 \cdot 6)$ & $\begin{array}{c}-16.0(10.6) \\
-2.0(8.5)\end{array}$ \\
\hline Buzzard et al. (1990) & Randomized & $\begin{array}{l}\text { Stage II } \\
\quad \text { breast cancer }\end{array}$ & 3 months & I & $\begin{array}{l}17 / 0 \\
11 / 0\end{array}$ & $\begin{array}{l}28 \cdot 6 \\
28.6\end{array}$ & $\begin{array}{l}-2.8(2.9) \\
-1.3(2.7)\end{array}$ & $1.5(-0.6$ to 3.6$)$ & $\begin{array}{r}-15.6(9.4) \\
-3.0(7.7)\end{array}$ \\
\hline Ornish et al. (1990) & Randomized & Coronary artery disease & 12 months & I & $\begin{array}{l}0 / 21 \\
4 / 15\end{array}$ & $\begin{array}{l}28 \cdot 4 \\
25 \cdot 4\end{array}$ & $\begin{array}{c}-10.0(19.2) \\
1.4(33.8)\end{array}$ & $11.4(-5.9$ to $28 \cdot 7)$ & $\begin{aligned} &-24.7(8.4) \\
&-0.6(13.7)\end{aligned}$ \\
\hline Bloemberg et al. (1991) & Randomized & Blood lipids & 26 weeks & I & $\begin{array}{l}0 / 39 \\
0 / 41\end{array}$ & $\begin{array}{l}26 \cdot 0 \\
26 \cdot 3\end{array}$ & $\begin{array}{l}-0.9(2.7) \\
+0.1(1.9)\end{array}$ & $1.0(0.0$ to 2.0$)$ & $\begin{array}{l}-5.0(6.5) \\
-1.5(5.9)\end{array}$ \\
\hline Sheppard et al. (1991) & Randomized & Weight loss & 12 months & I & $\begin{array}{l}171 / 0 \\
105 / 0\end{array}$ & $\begin{array}{l}26 \\
25\end{array}$ & $\begin{array}{r}-3.0(4.8) \\
0.4(3.5)\end{array}$ & $3.4(2.4$ to 4.4$)$ & $\begin{array}{r}-17.6(8.5) \\
+1.7(7.8)\end{array}$ \\
\hline Baer (1993) & Non-randomized & Blood lipids & 12 months & I & $\begin{array}{l}0 / 33 \\
0 / 37\end{array}$ & $\begin{array}{l}26 \cdot 5 \\
24.7\end{array}$ & $\begin{array}{r}-5.0(14.9) \\
1.0(21.9)\end{array}$ & $6.0(-2.7$ to 14.7$)$ & $\begin{array}{l}-7.0(24.3) \\
-1.0(38.0)\end{array}$ \\
\hline Hunninghake et al. (1993) & $\begin{array}{r}\text { Randomized } \\
\text { cross-over }\end{array}$ & Blood lipids & 9 weeks & I & $40 / 65$ & $26 \cdot 0$ & $\begin{array}{r}-1.4(36.1) \\
0.0(36.1)\end{array}$ & $1.4(-8.6$ to 11.4$)$ & $\begin{array}{r}-15.6(14.7) \\
0.0(14.7)\end{array}$ \\
\hline Kasim et al. (1993) & Randomized & Blood lipids & 12 months & I & $\begin{array}{l}34 / 0 \\
38 / 0\end{array}$ & $\begin{array}{l}25 \cdot 2 \\
28 \cdot 1\end{array}$ & $\begin{array}{l}-3.4(16.1) \\
-0.8(16.9)\end{array}$ & $2.6(-4.8$ to $10 \cdot 0)$ & $\begin{array}{r}-18.7(9.1) \\
-1.8(10.0)\end{array}$ \\
\hline Raben et al. (1995) & Non-randomized & Blood lipids & 11 weeks & I & $\begin{array}{l}6 / 18 \\
8 / 16\end{array}$ & $\begin{array}{l}21 \cdot 8 \\
21 \cdot 1\end{array}$ & $\begin{array}{r}-1.4(1.9) \\
0.0(1.0)\end{array}$ & $1.4(0.5$ to 2.3$)$ & $\begin{array}{c}-11.8(12.7) \\
0.0(4.8)\end{array}$ \\
\hline Pritchard et al. (1996) & Randomized & Body composition & 12 weeks & I & $\begin{array}{l}0 / 18 \\
0 / 19\end{array}$ & $\begin{array}{l}28.9 \\
28.7\end{array}$ & $\begin{array}{r}-6.4(10.8) \\
0.0(12.3)\end{array}$ & $6.4(-1.0$ to 13.8$)$ & $\begin{array}{r}-12.8(2.1) \\
+0.7(1.9)\end{array}$ \\
\hline Siggaard et al. (1996) & Non-randomized & Body composition & 12 weeks & I & $\begin{array}{l}2 / 47 \\
2 / 14\end{array}$ & $\begin{array}{l}28 \cdot 4 \\
27 \cdot 0\end{array}$ & $\begin{array}{c}-4.2(2.7) \\
0.8(1.9)\end{array}$ & $3.4(2.2$ to 4.6$)$ & $\begin{array}{r}-11.0(10.7) \\
-1.6(6.6)\end{array}$ \\
\hline Simon et al. (1997) & Randomized & Breast cancer prevention & 12 months & I & $\begin{array}{l}65 / 0 \\
68 / 0\end{array}$ & ND & $\begin{array}{l}-1.6(22.1) \\
-2.3(17.4)\end{array}$ & $-0.7(-7.5$ to 6.1$)$ & $\begin{array}{r}-18.0(8.8) \\
-0.9(10.0)\end{array}$ \\
\hline Weststrate et al. (1998) & Randomized & Body weight blood lipids & 6 months & I & $\begin{array}{l}58 / 59 \\
51 / 52\end{array}$ & $\begin{array}{l}24 \cdot 8 \\
25 \cdot 0\end{array}$ & $\begin{array}{l}+0.4(14.7) \\
+1.1(14.7)\end{array}$ & $0.7(-3 \cdot 2$ to $4 \cdot 6)$ & $\begin{array}{l}-3.0(4.6) \\
+5.0(6.5)\end{array}$ \\
\hline Stefanick et al. (1998) & Randomized & Blood lipids & 12 months & I & $\begin{array}{l}46 / 0 \\
45 / 0\end{array}$ & $26 \cdot 3$ & $\begin{array}{l}-2.7(3.5) \\
+0.8(4.2)\end{array}$ & $3.5(1.9$ to 5.1$)$ & $\begin{array}{l}-5.7(7.4) \\
-0.2(6.7)\end{array}$ \\
\hline Stefanick et al. (1998) & Randomized & Blood lipids & 12 months & I & $\begin{array}{l}0 / 49 \\
0 / 46\end{array}$ & $27 \cdot 0$ & $\begin{array}{l}-2.8(3.5) \\
+0.5(2.7)\end{array}$ & 3.3 (2.0 to 4.6$)$ & $\begin{array}{l}-8.0(8.1) \\
-0.7(5.9)\end{array}$ \\
\hline & Overall & & & I & $\begin{array}{l}568 / 349=917 \\
506 / 305=811\end{array}$ & & & & \\
\hline
\end{tabular}


2 months $(n=47)$; if the energy intake was adjusted to maintain body weight $(n=9)$; if total energy intake was restricted $(n=48)$; if there were other interventions which could affect weight loss apart from advice to increase physical activity $(n=12)$; if the study involved patients with non-insulin-dependent diabetes mellitus $(n=6)$; if drugs were given which may have affected weight loss $(n=$ $5)$; if no proper control group existed $(n=19)$; or if no numerical values for the pre-treatment and final body weights and/or the pre-treatment and final dietary fat intake were provided $(n=41)$. If results from the same study were reported in more than one publication, the data were included only once $(n=15)$. A total of 15 publications reporting 16 studies met the inclusion criteria (Lee-Han et al. 1988; Boyd et al. 1990; Buzzard et al. 1990; Ornish et al. 1990; Bloemberg et al. 1991; Sheppard et al. 1991; Baer, 1993; Hunninghake et al. 1993; Kasim et al. 1993; Raben et al. 1995; Pritchard et al. 1996; Siggaard et al. 1996; Simon et al. 1997; Stefanick et al. 1998; Weststrate et al. 1998). These studies included a total of 1728 individuals, 1074 women and 654 men. Thirteen studies were randomized controlled trials (Table 1), 12 using a parallel design and one using a crossover design. The control groups were advised either to maintain their regular diet or to consume a diet with a fat content as in the background population. Body mass index was not reported in all the studies, and height was not reported. The mean body mass index of the studies was estimated to be $21-29 \mathrm{~kg} / \mathrm{m}^{2}$.

\section{Results}

The low-fat interventions produced reductions in percentage of energy from fat ranging from 3.5 to $24 \cdot 1$ as compared to the control groups (Table 1). The corresponding weight losses ranged from 11.4 to $-0.77 \mathrm{~kg}$. The low-fat interventions as compared with the control groups produced a weight loss of $2.40 \mathrm{~kg}$ more $(95 \% \mathrm{CI}, 1.93-2.87 ; P<$ $0.0001)$ in the fixed effects analysis and $2.52 \mathrm{~kg}$ more $(1.51-3.53 ; P<0.0001)$ in the random effects analysis (Fig. 1). As a further sensitivity analysis, we eliminated one study in which the intervention produced the greatest weight loss and in which an organized physical activity programme was included (Ornish et al. 1990), and repeated the analyses. The results were very similar. The estimated difference was $2.39 \mathrm{~kg}(1.92-2.86 ; P<$ $0 \cdot 0001)$ in the fixed effects analysis and 2.53 (1.97-3.09; $P<0.0001)$ in the random effects model. In a simple correlation analyses the major determinant of the weight loss difference was pre-treatment body weight $(r=0.52$, $P<0.05$ ) (Fig. 2). After adjustment for pre-treatment body weight, there was a dose-response relationship between the reduction in percentage dietary fat intake and weight loss $(r=0.66, P<0.005)$ (Fig. 3). With no change in percentage dietary fat intake, no weight change occurred (intercept with $0: P=0 \cdot 14$ ). The slope of the relation indicated that for every $1 \%$ reduction in dietary fat, a weight loss of $0.37 \mathrm{~kg}(95 \% \mathrm{CI}, 0.15$ to $0.60 \mathrm{~kg} / \%$ ) was achieved. Weight loss was not associated with the duration of the intervention. Reduction of energy intake was not associated with weight loss when pre-treatment body weight and dietary fat reduction were controlled for.

The analysis indicated that only minor weight loss occurred in groups with body weights in the normal range $(60-72 \mathrm{~kg})$, but this group did not experience the slight weight gain seen in the control groups consuming

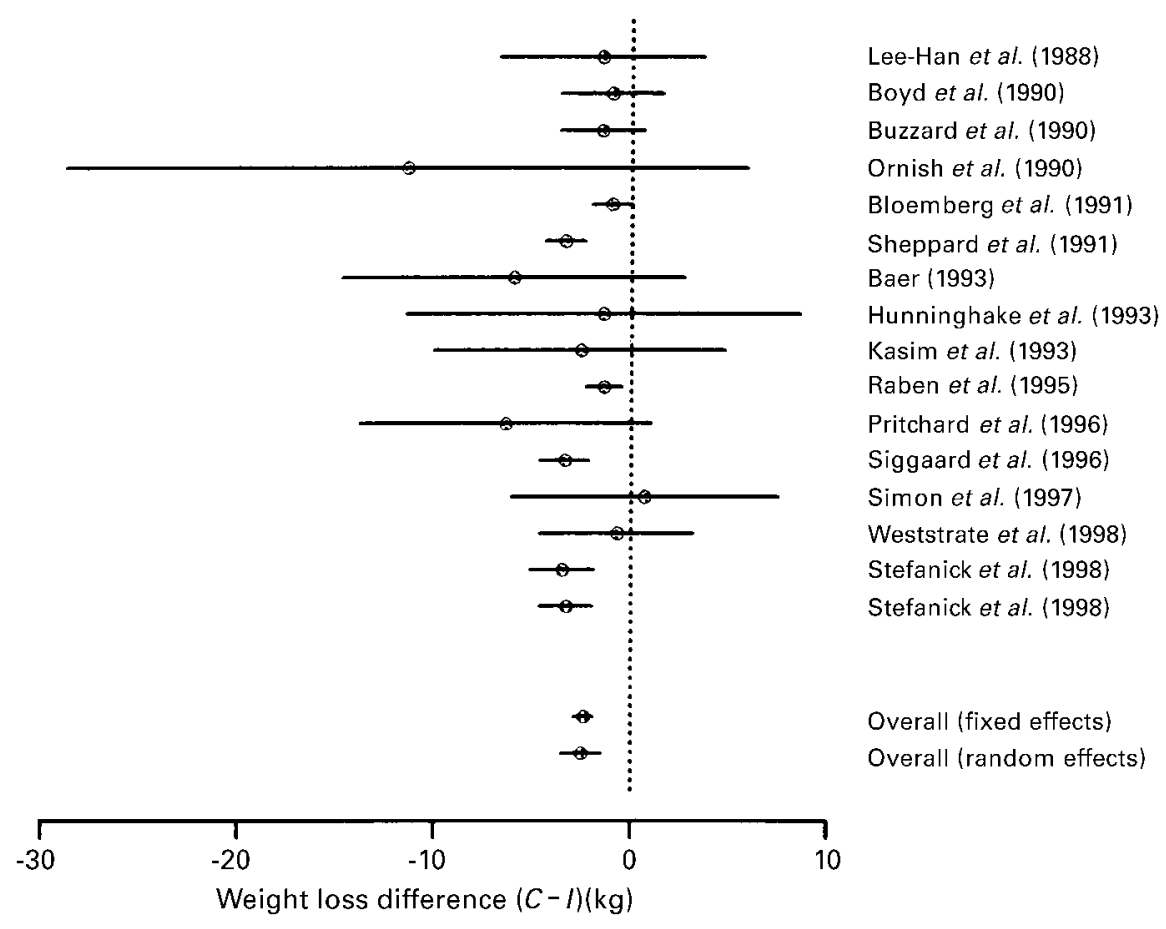

Fig. 1. Estimated differences in weight loss (intervention minus control) $(\mathrm{kg})$ with $95 \% \mathrm{Cl}$ for 16 studies included in the meta-analysis. The estimates and $95 \% \mathrm{Cl}$ from the fixed effects and random effects meta-analysis are also shown. 


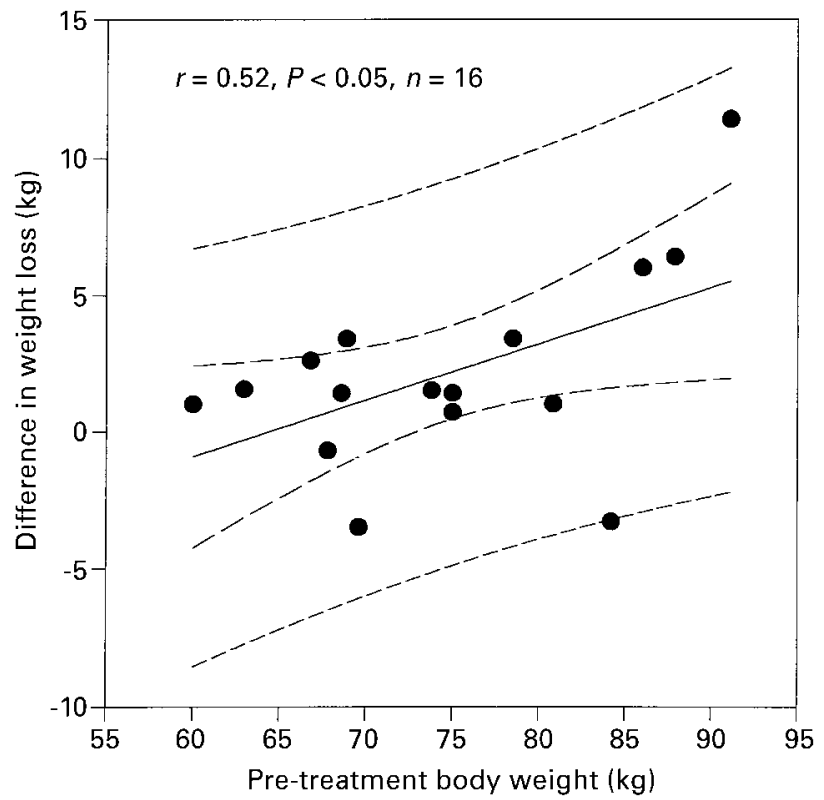

Fig. 2. The unweighted association between study means of difference in weight loss and pre-treatment body weight. Each dot represents the mean difference (intervention minus control) in weight loss during the intervention of each of the 16 studies versus the pretreatment mean body weight of each study.

normal- fat diets. Weight loss increased progressively with increasing initial body weight. Extrapolated to a body weight of $88 \mathrm{~kg}$ (corresponding to a BMI of about $30 \mathrm{~kg} / \mathrm{m}^{2}$ ), and assuming a $10 \%$-point fat reduction, the predicted weight loss would be $4.4 \mathrm{~kg}$ (95\% CI, 2.0$6 \cdot 8 \mathrm{~kg})$.

\section{Discussion}

Another meta-analysis used more liberal inclusion criteria and was based on 37 dietary intervention studies published from 1981 to 1997 (Yu-Poth et al. 1999). The weight loss in the intervention groups was $2.79 \mathrm{~kg}$ larger than in the control group, and there was a highly significant relation between reduction in dietary fat and weight loss, so that for every $1 \%$ decrease in energy from fat there was a $0.28 \mathrm{~kg}$ decrease in body weight. These two studies show that a reduction in dietary fat without restriction of total energy intake causes weight loss in a dose-dependent fashion and may produce a modest, but clinically relevant, weight loss in overweight subjects.

\section{Importance of carbohydrate source for obesity and glycaemic index for obesity and risk factors}

The relative contributions of the carbohydrate sources in the diet may have potential implications for body weight regulation and obesity. The intake of alcohol and protein has remained relatively constant in most EU countries

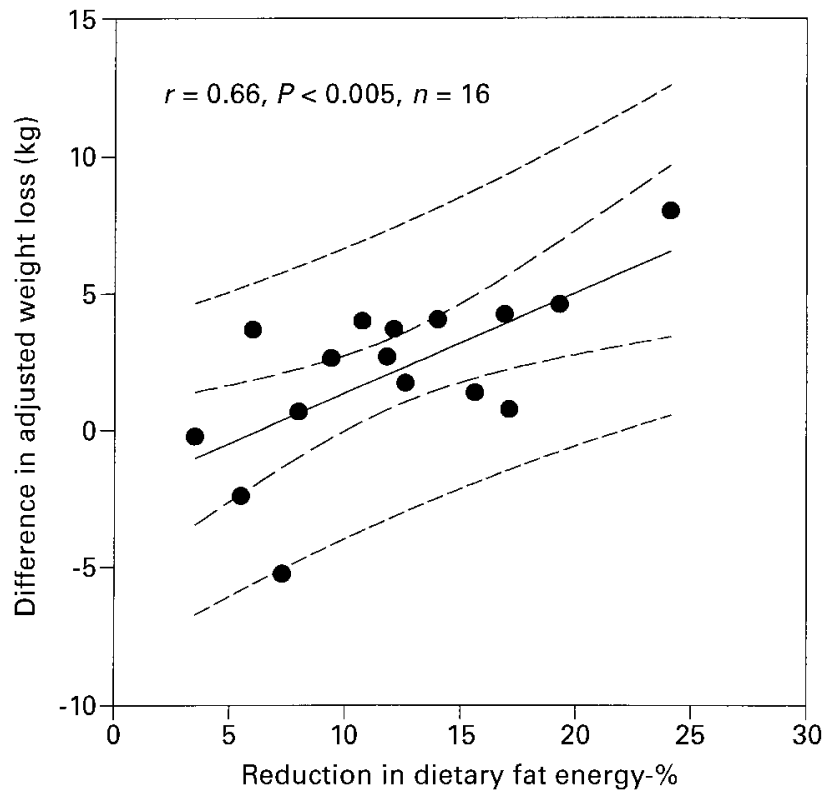

Fig. 3. The unweighted association between study means of difference in weight loss, adjusted for pre-treatment body weight, and change in percentage of dietary energy from fat. The weight loss and the change in percentage dietary fat are calculated as the difference between mean changes in intervention and control groups.

over the past 50 years, and together these nutrients represent less than $20 \%$ of the total energy intake. The main dietary change has been the increase in fat intake at the expense of carbohydrates. The inverse relationship between dietary fat and carbohydrate has been demonstrated in numerous cross-sectional studies in countries with very different socio-economic status. It is particularly the simple sugars, and not the complex carbohydrates, which tend to counterbalance the fat energy of the diet. This phenomenon has been dubbed the 'fat-sugar seesaw'. Cross-sectional observational studies have consistently shown a negative association between body weight and the proportion of dietary carbohydrate, and in particular with simple sugars. One of the largest data sets is derived from the Scottish part of the Monica Survey and clearly shows an inverse relationship between sugar intake and obesity (Bolton-Smith \& Woodward, 1994). When divided into quintiles according to the fat:sugar ratio, there was a two- to threefold higher prevalence of obesity in the highest versus the lowest quintile. One of the shortcomings of cross-sectional surveys is the possibility that the dietary pattern may represent a post hoc event, whereby obese individuals have adopted a particular diet composition consequent to their obesity. For example, if obese subjects have replaced sugars with artificial sweeteners in an effort to reduce their energy intake, their sugar intake will be low. Experimental studies and short-term intervention studies do not produce a firm conclusion, as some studies suggest that low-fat, high-sugar diets may increase energy intake above that of a similar low-fat diet with a high complex carbohydrate content. The only available long-term study is the European multi-centre 
trial CARMEN (W. Saris et al. unpublished results). In this study 398 overweight and obese adults with a BMI between 26 and 35 were randomized to a dietary intervention of either a low-fat, high simple carbohydrate diet, or a low-fat, high complex carbohydrate diet, or to a continuation of the control diet. The diets were supplied by a validated laboratory shop system. A diet low in fat and with an increased level of complex carbohydrates lowered body fat mass with $2.4 \mathrm{~kg}$ more than the control diet. To a lesser extent it also reduced fat mass compared to the control diet $(1.9 \mathrm{~kg})$. Although the difference in weight loss between complex and simple carbohydrate groups was not statistically significant, it is possible that the low-fat, simple-carbohydrate diet is slightly less effective in inducing weight loss. It should be noted that there was no difference in energy density between the two low-fat diets in the CARMEN study. Given the important role of energy density in passive overconsumption, the introduction of low-fat foods, such as cakes and biscuits, in which fat is substituted by simple sugars but energy density is unchanged, may impair the expected decrease in energy intake and hence play a role in maintaining an excessive body weight in some subjects.

\section{Effects of low-fat, high-carbohydrate diets on risk factors}

Some evidence is available for a differential effect of carbohydrate sources on insulin resistance, blood lipids and other cardiovascular risk factors. It is often argued that a reduction in total fat intake, accompanied by a rise in carbohydrate intake, leads to a rise in plasma triglycerides and a fall in plasma HDL-cholesterol, which would be expected to increase the risk of CHD. Furthermore it has been suggested that mono-unsaturated fat has a more beneficial effect on risk factors of CHD than carbohydrate. This is true in studies where carbohydrate has been compared with mono-unsaturated fat under strictly isoenergetic conditions and no weight loss was allowed to occur on the low-fat, complex carbohydrate diet (Luscombe et al. 1999). But in the studies allowing ad libitum intake the changes in blood lipids are dominated by the slight weight loss induced by the low-fat diet. This was illustrated in a study on hyperlipidaemic patients where the dietary fat content was first changed from 35 to 15 energy per cent under isoenergetic conditions so that body weight was kept constant (Schaefer et al. 1995). After 6 weeks total cholesterol was reduced by $13 \%$ and LDL-cholesterol by $17 \%$, but HDLcholesterol decreased by $23 \%$ and plasma triglycerides increased by $47 \%$. Subsequently, the patients continued for a further 10-12 weeks on an ad libitum diet of the same composition. Now the diet caused a mean weight loss of $3.6 \mathrm{~kg}$, a further reduction in LDL-cholesterol, and the normalization of plasma triglycerides and the ratio of HDL-cholesterol/total cholesterol. This has been confirmed in a systematic review and meta-analysis evaluating the effects of the American National Cholesterol Education Program's dietary interventions on major cardiovascular disease risk factors (Yu-Poth et al. 1999).

However, the carbohydrate source and the glycaemic index may have importance for the effect on risk factors. Both observational and intervention studies show that a low glycaemic index diet exerts more beneficial effects than a high glycaemic index diet on LDL- and HDL-cholesterol, insulin resistance, and plasminogen activator inhibitor-1 activity (Frost et al. 1999; Jarvi et al. 1999). Consequently, the high carbohydrate content of low-fat diets should stem mainly from the complex carbohydrates of different vegetables, fruits and whole grains, which are more satiating for fewer calories than fatty foods and are good sources of vitamins, minerals, trace elements and fibre. A high fibre content may further improve the satiating effect of the diet, and a diet rich in soluble fibre, including oat bran, legumes, barley and most fruits and vegetables, may have the most beneficial effect on blood lipids and blood pressure levels.

In conclusion, there is little evidence to support the idea that differences in carbohydrate source may be important for body weight regulation and propensity to obesity. While short-term studies suggest that foods with a low glycaemic index exert a stronger effect on satiety than those with a high index, long-term studies are lacking and the importance for body fatness is unknown.

\section{The role of protein for obesity and risk factors}

There is some concern that a high protein intake in infant formulas and during growth may increase the susceptibility to weight gain and obesity. However, there is a large body of experimental data to suggest that protein possesses a higher satiating power per calorie than carbohydrate and fat in adults. The impact on obesity and risk factors of replacing carbohydrate with protein in ad libitum low-fat diets has been addressed in only one trial. Two fat-reduced diets (30\% of total energy), a high-carbohydrate diet (protein $12 \%$ of total energy) and a high-protein diet (protein $25 \%$ of total energy) were compared in 65 obese patients (Skov et al. 1999). Weight loss after 6 months was $5 \cdot 1 \mathrm{~kg}$ in the high-carbohydrate and $8.9 \mathrm{~kg}$ in the high-protein groups, and more subjects lost $>10 \mathrm{~kg}$ in the high-protein group $(35 \%)$ than in the high-carbohydrate group $(9 \%)$. The protein-rich diet had no adverse effect on blood lipids, renal function or bone mineral density. More freedom to choose between protein-rich and complex carbohydrate-rich foods may encourage obese subjects to choose more lean meat and dairy products and hence improve adherence to low-fat diets in weight-reduction programmes.

The consumption of meat and meat products has been linked epidemiologically to cancers at different sites. Ecological studies of diet and cancer have tended to show a correlation between meat intake, particularly red meat, and the risk of colo-rectal cancer, but more recent European case referent studies have failed to show any relationship (Hill, 1999). The available evidence points to the intake of protective factors such as vegetables and whole-grain cereals being the main determinants of colo-rectal cancer risk, with meat intake being only coincidentally related (Hill, 1999). The type, amount, processing, cooking and dose responses of meat or protein responsible for the increased risk of other cancers is uncertain, and the current recommendation for a $140 \mathrm{~g}$ limit is a pragmatic value, based on the distribution of meat intake in the UK population (Bingham, 1999).

In conclusion, the available evidence suggests that a diet 
with a protein content up to 25 energy per cent may be beneficial for weight regulation in adults. Increased protein allowances in weight reduction diets should await confirmation of the positive results by more randomized trials.

\section{Conclusions}

Systematic reviews and two meta-analyses show that $a d$ libitum low-fat diets prevent weight gain in normal-weight subjects and consistently cause weight loss in overweight subjects. Whereas the magnitude of body weight decline may be modest in overweight individuals and $4-5 \mathrm{~kg}$ in obese individuals, the greatest benefit of a low-fat diet may be in preventing weight gain. The weight loss may be further increased by optimizing the dietary ratio of protein to carbohydrate and potentially by choosing mainly low glycaemic-index foods. A mean decrease in population body weight of $2.5 \mathrm{~kg}$ may be sufficient to cut the prevalence of obesity from 20 to $10 \%$, so even a few kilograms weight loss on a low-fat diet may therefore have an important public health impact. Based on these results, reversing public health messages to limit dietary fat could exacerbate the epidemic of obesity and its associated health consequences.

\section{Acknowledgements}

This study was supported by grants from the Danish Medical Research Council and the Danish Food Technology and Nutrition Program (FØTEK); NIH grants DK42549 and DK48520 (Hill).

\section{References}

Astrup A, Toubro S, Raben A \& Skov AR (1997) The role of low fat diets and fat substitutes in body weight management: what have we learned from clinical studies? Journal of the American Dietetics Association 97, 82S-87S.

Baer JT (1993) Improved plasma cholesterol levels in men after a nutrition education program at the worksite. Journal of the American Dietetics Association 93, 658-663.

Bennett C, Reed GW, Peters JC, Abumrad NN, Sun M \& Hill JO (1992) Short-term effects of dietary-fat ingestion on energy expenditure and nutrient balance. American Journal of Clinical Nutrition 55, 1071-1077.

Bingham SA (1999) High-meat diets and cancer risk. Proceedings of the Nutrition Society 58, 243-248.

Bloemberg BPM, Kromhout D, Goddijin E, Jansen A \& Obermann-de Boer GL (1991) The impact of the guidelines for a healthy diet of the Netherlands Nutrition Council on total and high density lipoprotein cholesterol in hypercholesterolemic free-living men. American Journal of Epidemiology 134, 39-48.

Bolton-Smith C \& Woodward M (1994) Dietary composition and fat to sugar ratios in relation to obesity. International Journal of Obesity 18, 820-828.

Boyd NF, Cousins M, Beaton M, Kriukov V, Lockwood G \& Tritchler D (1990) Quantative changes in dietary fat intake and serum cholesterol in women: results from a randomized, controlled trial. American Journal of Clinical Nutrition 52, 470476.

Bray GA \& Popkin BM (1998) Dietary fat intake does affect obesity. American Journal of Clinical Nutrition 68, 1157-1173.

Buzzard IM, Chlebowski RT, Jeffery RW et al. (1990) Diet intervention methods to reduce fat intake: nutrient and food group composition of self-selected low-fat diets. Journal of the American Dietetics Association 53, 42-50.

Hill MJ (1999) Meat and colo-rectal cancer. Proceedings of the Nutrition Society 58, 261-264.

Hunninghake DB, Stein EA, Dujovne CA et al. (1993) The efficacy of intensive dietary therapy alone or combined with lovastatin in outpatients with hupercholesterolemia. New England Journal of Medicine 328, 1213-1219.

Frost G, Leeds AA, Doré CJ, Madeiros S, Brading S \& Dornhorst A (1999) Glycaemic index as a determinant of serum HDLcholesterol concentration. Lancet 353, 1045-1048.

Jarvi AE, Karlstrom BE, Granfeldt YE, Bjorck IE, Asp NG \& Vessby B (1999) Improved glycemic control and lipid profile and normalized fibrinolytic activity on a low-glycemic index diet in type 2 diabetic patients. Diabetes Care 22, 10-18.

Kant AK, Graubard BI, Schatzkin A \& Ballard-Barbash R (1995) Proportion of energy intake from fat and subsequent weight change in the NAHNES I Epidemiologic Follow-up Study. American Journal of Clinical Nutrition 61, 11-17.

Kasim SE, Martino S, Kim P, Khilnani S, Boomer A, Depper J, Reading BA \& Heilbrun LK (1993) Dietary and anthropometric determinants of plasma lipoproteins during a long-term low-fat diet in healthy women. American Journal of Clinical Nutrition 57, 146-153.

Katan MB, Grundy SM \& Willett WC (1997) Beyond low-fat diets. New England Journal of Medicine 337, 563-566.

Lee-Han H, Cousins M, Beaton M, McGuire V, Kriukov V, Chipman M \& Boyd N (1988) Compliance in a randomized clinical trial of dietary fat reduction in patients with breast dysplasia. American Journal of Clinical Nutrition 48, 575-586.

Luscombe ND, Noakes M \& Clifton PM (1999) Diets high and low in glycemic index versus high monounsaturated fat diets: effects on glucose and lipid metabolism in NIDDM. European Journal of Clinical Nutrition 53, 473-478.

Ornish D, Brown SE, Scherwitz LW, Billings JH, Armstrong WT, Ports TA, McLanahan SM, Kirkeeide RL, Brand RJ \& Gould KL (1990) Can lifestyle changes reverse coronary heart disease? Lancet 336, 129-133.

Paeratakul S, Popkin BM, Keyou G, Adair LS \& Stevens J (1998) Changes in diet and physical activity affect the body mass index of Chinese adults. International Journal of Obesity and Related Metabolic Disorders 22, 424-431.

Prentice AM, Black AE, Coward WA, Davies HL, Goldberg GR, Murgatroyd PR, Ashford J, Sawyer M \& Whitehead RG (1986) High levels of energy expenditure in obese women. British Medical Journal 292, 983-992.

Pritchard JE, Nowson CA \& Wark JD (1996) Bone loss accompanying diet-induced or exercise-induced weight loss: a randomised controlled study. International Journal of Obesity 20, 513-520.

Raben A, Due Jensen N, Marckmann P, Sandstrom B \& Astrup A (1995) Spontaneous weight loss during 11 weeks' ad libitum intake of a low fat/high fiber diet in young, normal weight subjects. International Journal of Obesity and Related Metabolic Disorders 19, 916-922.

Radimer KL \& Harvey PWJ (1998) Comparison of self-report of reduced fat and salt foods with sales and supply data. European Journal of Clinical Nutrition 52, 380-382.

Schaefer EJ, Lichtenstein AH, Lamon-Fava S, McNamara JR, Schaefer MM, Rasmussen H \& Ordovas JM (1995) Body weight and low-density lipoprotein cholesterol changes after consumption of a low-fat ad libitum diet. Journal of the American Medical Association 274, 1450-1455.

Schoeller DA (1990) How accurate is self reported dietary intake? Nutrition Reviews 48, 373-379.

Sheppard L, Kristal AR \& Kushi LH (1991) Weight loss in women 
participating in a randomized trial of low-fat diets. American Journal of Clinical Nutrition 54, 821-828.

Siggaard R, Raben A \& Astrup A (1996) Weight loss during 12 weeks ad libitum carbohydrate-rich diet in overweight and normal weight subjects at a Danish working site. Obesity Research 4, 347-356.

Simon MS, Heilbrun LK, Boomer A, Kresge C, Depper J, Kim PN, Valeriote F \& Martino S (1997) A randomized trial of a low-fat dietary intervention in women at high risk for breast cancer. Nutrition and Cancer 27, 136-142.

Skov AR, Toubro S, Rønn B, Holm L \& Astrup A (1999) Randomized trial on protein versus carbohydrate in ad libitum fat reduced diet for the treatment of obesity. International Journal of Obesity 23, 528-536.

Stefanick ML, Mackey S, Sheehan M, Ellsworth N, Haskell WL \& Wood PD (1998) Effects of diet and exercise in men and postmenopausal women with low levels of HDL cholesterol and high levels of LDL cholesterol. New England Journal of Medicine 339, 12-20.
Stubbs RJ, Harbron CG, Murgatroyd PR \& Prentice AM (1995) Covert manipulation of dietary fat and energy density: effect on substrate flux and food intake in men eating ad libitum. American Journal of Clinical Nutrition 62, 316-329.

Weststrate JA, van het Hof $\mathrm{KH}$, van den Berg H, Velthuis-teWierik EJ, de Graaf C, Zimmermanns NJ, Westerterp KR, Westerterp-Plantenga MS \& Verboeket-van de Venne WP (1998) A comparison of the effect of free access to reduced fat products or their full fat equivalents on food intake, body weight, blood lipids and fat-soluble antioxidants levels and haemostasis variables. European Journal of Clinical Nutrition 52, 389-395.

Willett WC (1998) Is dietary fat a major determinant of body fat? American Journal of Clinical Nutrition 67, 556S-562S.

Yu-Poth S, Zhao G, Etherton T, Naglak M, Jonnalagadda S \& KrisEtherton PM (1999) Effects of the National Cholesterol Education Program's step I and step II dietary intervention programs on cardiovascular disease risk factors: a meta-analysis. American Journal of Clinical Nutrition 69, 632-46. 